\title{
Charitable Trusts to Effect Changes in the Law
}

$T$ HE recent decision in Collier v. Lindley, ${ }^{1}$ holding valid the charitable purposes of the trust established by Dr. John Randolph Haynes, a regent of the University of California, and his wife, Dora, raises some interesting points relative to charitable trusts:

"A charitable trust or a charity is a donation in trust for promoting the welfare of mankind at large, or of a community, or of some class forming a part of it, indefinite as to numbers and individuals. It may, but it need not, confer a gratuitous benefit upon the poor. It may, but it need not, look to the care of the sick or insane. It may, but it need not, seek to spread religion or piety. Schools and libraries, equally with asylums, hospitals, and religious institutions, are included within its scope. It is impossible to enumerate specifically all purposes for which an eleemosynary trust may be created. The difficulty is inherent in the subject matter itself. With the progress of civilization new needs are developed, new vices spring up, new forms of human activity manifest themselves, any or all of which, for their advancement or suppression, may become the proper objects of an eleemosynary trust."'

"The enforcement of charitable uses cannot be limited to any narrow and stated formula. As has been well said, it must expand with the advancement of civilization and the daily increasing needs of men. New discoveries in science, new fields and opportunities for human action, the differing condition, character, and wants of communities and nations, change and enlarge the scope of charity, and where new necessities are created new charitable uses must be established. The underlying principle is the same; its application is as varying as the wants of humanity." 3

The purposes of the Haynes Foundation are set forth as follows:

"Paragraph Sixth: The trustees shall hold the said trust estate in trust for the following uses and purposes:

"Sec. I. To promote and assist in promoting and obtaining, maintaining and making improvements in the structure and methods of government, national, state and/or local, by obtaining, protecting, preserving, and/or furthering, by any or all legitimate ways,

"(a) The public ownership and operation of public utilities.

1 (March 26, 1928) 75 Cal. Dec. 459, 266 Pac. 526.

2 People v. Cogswell (1896) 113 Cal. 129, 138, 45 Pac. 270,35 L. R. A. 269.

3 People v. Dashaway Assn. (1890) 84 Cal. 114, 122, 24 Pac. 277, 12 L. R. A. 117. 
"(b) Direct legislation, now known as the Initiative, Referendum and Recall.

"(c) Such improvements in the direct, popular nomination and election of public officials as will enable the electorate to vote more intelligently and efficiently; simplify nomination and election procedure; and insure a more adequate representation in government of the important groups.

"(d) Assisting in the making, amending, and/or reviewing of city charters, county charters, and state and national constitutions.

"Sec. II. (a) Improve living conditions of the working people by investigating the causes of poverty, preventing the operation of such causes, and remedying or ameliorating the conditions resulting therefrom, by any legitimate means.

"(b) To study, investigate and encourage the introduction into the United States of America of the co-operative system of selling and purchasing food, household and other requirements, under the system generally known as the 'Rochdale System of Co-operation.'

"Sec. III. To inprove working conditions for men, women and children by:

"(a) Investigating the causes of industrial accidents and diseases; including, among other things, the relation of hours of labor to the health of workers, and the conditions under which work is performed;

"(b) Helping, by all lawful means, to prevent the continuance of conditions inimical to the health, welfare and safety of workers, and helping to secure better working conditions for them.

"Sec. IV. To induce, encourage and support industrial cooperation, to the end that justice may be done to employer and employee alike, and harmony be established and maintained between them, and industrial hatred and strife abolished, thereby benefiting mankind in general.

"Sec. V. To encourage and give educational opportunities for the study of-

"(a) Governmental problems and reforms furthering 'Government of the people, by the people, and for the people';

"(b) Industrial problems with special reference to improvements in living and working conditions of the working people;

"(c) Social problems with special reference to improvements in health, sanitation and morals of the working people;

by paying wholly, or partially, lecturers and instructors on matters included in this Section V, and/or by furnishing appropriate books and literature on these matters, and/or by donations to institutions or organizations to be applied in furthering the causes in this section designated, and/or by assisting in obtaining or supporting, or helping to enforce legislation for such purposes, or any of them. 
"Sec. VI. To further the improvement of the human race by aiding and encouraging the science of eugenics, which deals with the heritable qualities of the human race; and by aiding and encouraging the practicable application of the principles of that science.

"Sec. VII. To assist in securing, maintaining, enforcing and strengthening prohibition and other legislation, rational, state and/or local, affecting the manufacture, and use, and/or disposition of alcoholic beverages and/or intoxicating liquors and/or narcotic drugs by all lawful means and/or by investigating the operation and enforcement of laws and ordinances relating to those questions, and the results flowing therefrom.

"Sec. VIII. To promote justice for the American Indian in the United States by assisting in procuring legislation and/or by stimulating the proper enforcement of legislation to that end, and/or by assisting individual, or bodies of, Indians in obtaining that justice.

"Sec. IX. To assist in preserving and strengthening the rights of the citizens of The United States to 'Freedom of speech . . . and peacefully to assemble, and to petition the government for redress of grievances,' by donations to particular institutions or bodies, operating wholly or partially, permanently, or temporarily, for those purposes."

The Haynes Foundation is thus seen to aim at the accomplishment of definite reforms along political, economic, and sociological lines. The means proposed are, in the main, to bring about collective action through educating public opinion, thus leading to a change in the habits and customs of the people, and to the passage and enforcement of laws.

Neither the general purpose nor the method is new in the development of charitable trusts. There are Foundations like the one to promote publication and distribution of the writings of Henry George, ${ }^{4}$ and the Pollak Foundation, that foster economic studies and publication of results; others like the Rockefeller Foundation devote themselves not only to the advancement of science, but to its useful application in the prevention and cure of diseases. However, it may be said generally that until quite recently charitable trusts were devoted more to ameliorating the condition of the poor and sick than to seeking out causes and trying to prevent them. Hospitals, old peoples' homes, and orphanages have a long history of endowment. The evils to be cured or lessened are apparent long before the method of preventing them is learned.

These older forms of charity occasionally required legislation to

4 George v. Braddock (1889) 45 N. J. Eq. 757, 18 Atl. 881, 14 Am. St. Rep. 754, 6 L. R. A. 511 . 
make them effective; but the legislation was incidental and could hardly be regarded as a prime purpose of the endowment.

An examination of the purposes of the Haynes Foundation shows that some of them depend entirely upon the passage of lawseven to a change in the state and national constitutions; and the question arises, how far can the purpose of accomplishing changes in the law be considered a charity?

Would an effort to legalize race track gambling, for example, be one for which a charitable foundation might be established? If not, where is the line to be drawn? What kind of laws may be promoted by a charitable trust?

The cases dealing with the subject are surprisingly few.

Jackson v. Phillips ${ }^{5}$ is an early case, passing on three trusts of political significance. The first was "for the preparation and circulation of books, newspapers, the delivery of speeches, lectures, and such other means as . . . will create a public sentiment that will put an end to negro slavery in this country." "The bequest itself," the court says, "manifests its immediate purpose to be to educate the whole people upon the sin of a man's holding his fellow man in bondage; and its ultimate object, to put an end to negro slavery in the United States; in either aspect, a lawful charity."

There was but one means of putting an end to negro slavery in the United States, and that was by the passage of a constitutional amendment.

In the same case the court held invalid a trust "to secure the passage of laws granting women . . . the right to vote; to hold office; to hold, manage, and devise property ; and all other civil rights enjoyed by men."

In this case the money was to be used "for the preparation and circulation of books, the delivery of lectures and such other means as [the trustees] may judge best."

The distinction made between the two trusts apparently was that one was for the employment of educational and other means for creating a public sentiment for putting an end to negro slavery, whereas the other was for procuring legislation, educational means being but one of the available methods. This distinction has been followed only in Massachusetts ${ }^{6}$ and has been rejected in all other

5 (1867) 96 Mass. 539.

6 Bowditch v. Attorney General (1922) 241 Mass. 168, 134 N. E. 796, 28

A. L. R. 713 . 
states where the question has been presented. ${ }^{7}$ It was easier to make that distinction in 1867 than now, for then the law-making power resided in the legislature (except for constitutional changes), and the creation of public sentiment favorable to a certain measure might or might not cause the legislature to act. Something more than creating public sentiment might be required. Nowadays in many states of the Union, public opinion can find direct expression through the initiative.

The trend of modern authority has been toward the upholding of trusts which have for their object the creation of a more enlightened public opinion, with a consequent change in laws having to do with human relations and rights in a republic such as ours $;^{8}$ and hence it is, bequests of money to trustees for the attainment of woman suffrage and other rights in the United States have been upheld. ${ }^{9}$ Trusts for the promotion of prohibition have been sustained..$^{10}$

What is a "more enlightened public opinion"? Who is to judge whether it be more or less enlightened? Some states have laws permitting the practice of vivisection, regarded by many as due to "enlightened public opinion." Yet the English courts have held" that a trust having for its object the total abolition of the practice of vivisection is valid, although this involves the repeal of an act of Parliament.

It would seem that wisdom or lack of it does not affect the validity of an educational trust. The courts would probably hold that the procuring of laws either permitting or preventing vivisection or requiring or preventing vaccination are equally valid charitable purposes.

A trust "to propagate the sacred writings of Joanna Southcoate" was upheld although these writings showed that their authoress was under the delusion that she was with child by the Holy Ghost, that she had conversation with the Devil and intercommunings with the spiritual world. In view of these things the Master of the Rolls said "I have found much that, in my opinion, is very foolish, but nothing which is likely to make persons who read them either immoral or irreligious. I cannot, therefore, say that this devise of the

7 Collier v. Lindley, supra, n. 1; Garrison v. Little (1898) 75 IIl. App. 402; George v. Braddock, supra, n. 4; Taylor v. Hoag (1922) $273 \mathrm{~Pa}$. 194, 116 Atl. 826, 21 A. L. R. 946.

8 Collier v. Lindley, supra, n. 1.

9 Garrison v. Little, supra, n. 7.

10 Haines v. Allen (1881) 78 Ind. 100, 41 Am. Rep. 555.

11 In re Foveaux [1895] 2 Ch. 501. 
testatrix is invalid by reason of the tendency of the writings of Joanna Southcoate."12 "A charitable gift may . . . be both absurd and valid."13

One judge goes so far as to say that "if the cause was dear to the heart of the testatrix, we see no reason why she should not be permitted to devote a portion of her estate to its advancement."14 There is, however, a limit upon charitable gifts to carry out purposes "dear to the heart of the donor." The purpose must not be unlawful. ${ }^{15}$ Neither must it be against public policy. ${ }^{16}$

The Collier case ${ }^{17}$ holds that the trust must be "unobjectionable from the viewpoint of ethics or morals." Here we are upon shifting ground. What is "objectionable from the viewpoint of ethics or morals?" Moral and ethical standards are continually changing. The answer in any given case depends upon the standards prevailing at the moment. An interesting illustration may be found in In re Bowman ${ }^{18}$ which traces the history of English law and opinion on what has been regarded as "blasphemous."

"It is indeed still blasphemy, punishable at comman law, scoffingly or irreverently to ridicule or impugn the doctrines of the Christian faith, and no one would be allowed to give or to claim any pecuniary encouragement for such purpose; yet any man niay, without subjecting hinself to any penal consequences, soberly and reverently examine and question the truth of those doctrines which have been assumed as essential to it. And I am not aware of any impediment to the application of any charitable fund for the encouragement of such inquiries."19

This view was adopted by the court in In re Bowman, ${ }^{20}$ in which the court says "It is really a question of public policy, which varies from time to time. It is to my mind almost shocking to hold in the twentieth century that the publications of Positivists, and other schools of philosophers, who do not admit, and probably even deny,

12 Thornton v. Howe (1862) 31 Beav. 14, 54 Eng. Rep. R. 1042.

13 Zollman, American Law of Charities, p. 149 (1924).

14 Garrison v. Little, supra, n. 7.

15 Attorney General v. Guise (1692) 2 Vern. 266, 23 Eng. Rep. R. 772, where the testator endeavored to found a trust for the purpose of violating the law of Scotland.

${ }_{16}$ In re Killen's Will (1925) 124 Misc. Rep. 720, 209 N. Y. Supp. 206, where a gift to "further the development of the Irish Republic" was held by an inferior court not to be a charity, as against public policy, as it had a tendency to embroil the United States with a friendly foreign power.

17 Collier v. Lindley, supra, n. 1.

18 In re Bowman [1915] 2 Ch. 447, Ann. Cas. 1917B, 1016.

${ }^{18}$ Shore v. Wilson (1842) 9 Cl. \& F. 355, 524, 525, 8 Eng. Rep. R. 450.

20 Supra, n. 18. 
the existence of a God, are necessarily blasphemous. I think the older view must now be regarded as obsolete, and any decision to that effect ought no longer to be followed." And so the court disapproved of a decision ${ }^{21}$ invalidating a "Legacy for the best essay on Natural Theology treated as a science, and sufficient when so treated and taught to constitute a true, perfect, and philosophical system of universal religion"; and also of a case ${ }^{22}$ holding that the plaintiff could not recover on a contract for the rental of premises to be used by the Liverpool Secular Society for the purpose of having lectures delivered there, the titles of typical ones being "The Character and Teachings of Christ; the former defective and the latter misleading." "The Bible shown to be no more inspired than any other book." These two cases overruled in In re Bowman were based upon the ground that Christianity is a part and parcel of the common law of the land, and that therefore, to support and maintain propositions indicated in the titles of the proposed lectures and essays was a violation of the first principles of law and could not be done without blasphemy.

A testamentary trust for the benefit of "the Infidel Society in Philadelphia for the purpose of building . . . a hall for the free discussion of religion, politics, etc." was held invalid. ${ }^{23}$ There can be no question that the purpose of "building a hall for the free discussion of religion, politics, etc." would now be held valid as a charitable trust. Apparently the court was alarmed by the fact that "the Infidel Society in Philadelphia" was to be the trustee, fearing that "the free discussion of religion, politics, etc." would be conducted so as to advocate doctrines contrary to the prevailing standards of ethics or morals. It was said in a later case:

"It may be regarded as settled in Pennsylvania, that a court of equity will not enforce a trust where its object is the propagation of atheism, infidelity, immorality or hostility to the existing form of government. A man . . may deny the existence of a God, and employ his fortune in the dissemination of infidel views, but should he leave his fortune in trust for such purposes, the law will strike down the trust as contra bonos mores. ${ }^{.24}$

In this case, as in the Collier case, the judges are in accord that the purposes of the trust must not be contra bonos mores. But will all courts agree that "the dissemination of infidel views" is "contra

21 Briggs v. Hartley (1850) 14 Jur. 683, 19 L. J. (N. S.) Ch. 416.

22 Cowan v. Milbourne (1867) L. R. 2 Ex. 230.

23 Zeisweiss v. James (1870) 63 Pa. 465, 3 Am. Rep. 558.

24 Manners v. Philadelphia Library Company (1880) $93 \mathrm{~Pa} .165,172,39$ An. Rep. 741. 
bonos mores"? Is atheism or infidelity contra bonos mores in a country that guarantees freedom of religious thought? All-courts might not agree with that of Pennsylvania on this subject.

How far must the "hostility to the existing form of government" go before that purpose may be declared invalid? One of the trust purposes in Jackson v. Phillips was ${ }^{25}$ "for the benefit of fugitive slaves who may escape from the slave-holding states of this infamous Union from time to time."

"Disregarding the self-evident declaration of 1776 , repeated in her own constitution of 1780 , that 'all men are born free and equal,' Massachusetts has since, in the face of those solemn declarations, deliberately entered into a conspiracy with other states to aid them in enslaving millions of innocent persons. I have long labored to help my native state out of her deep iniquity and her barefaced hypocrisy in this matter. I now enter my last protest against her inconsistency, her injustice, and her cruelty, towards an unoffending people. God save the fugitive slaves that escape to her borders, whatever may become of the Commonwealth of Massachusetts!"

In passing upon this trust the court said:

"The Constitution of the United States, at the time of the testator's death, declared that no person held to service or labor in one state should be discharged therefrom by escaping into another. It may safely be assumed that, under such a constitution, a bequest to assist fugitive slaves to escape from those to whom their service was thus recognized to be due could not have been upheld and enforced as a lawful charity. The epithets with which the testator accompanied this bequest show that he set his own ideas of moral duty above his allegiance to his state or his country; and warrant the conjecture that he would have been well pleased to have the fund applied in a manner inconsistent with the Constitution and laws of the United States. But he has used no words to limit its use to illegal methods, and has left his trustees untrammeled as to the mode of its application."

There is no question, however, that the advocacy of "the destruction or overthrow of government or the criminal destruction of property"28 is such "hostility to the existing form of government" that a trust to advocate it would be invalid. The right to advocate these things is not included in the right of freedom of speech. ${ }^{27}$

It is clear, then, that a charitable trust may have for its purpose the advancement through legislation of a cause neither unlawful nor against public policy. But the legislation must be obtained by

25 Jackson v. Phillips, supra, n. 5 .

20 People v. Steelik (1921) 187 Cal. 361, 375, 203 Pac. 78.

27 People v. Steelik, supra, n. 26. 
legal methods. "Lobbying" as defined in the Constitution of California is prohibited.

"Any person who seeks to influence the vote of a member of the Legislature by bribery, promise of reward, intimidation, or any other dishonest means, shall be guilty of lobbying, which is hereby declared a felony."28 But "open advocacy of" an act "before the legislature or any committee thereof in open session" is law full ${ }^{29}$ even though the act sought to be passed be contrary to public policy ${ }^{30}$ though in the latter case it could not be the purpose of a charitable trust. ${ }^{31}$

The true rule concerning trusts to secure changes in existing laws has been well summed up as follows:

"We are led to conclude that a trust for a public charity is not invalid merely because it contemplates the procuring of such changes in existing laws as the donor deems beneficial to the people in general, or to a class for whose benefit the trust is created. To hold that an endeavor to procure by proper means a change in a law is in effect to attempt to violate that law would discourage improvement in legislation and tend to compel us to continue indefinitely to live under laws designed for an entirely different state of society. Such view is opposed to every principle of our government, based on the theory that it is a government 'of the people, by the people, and for the people, and fails to recoguize the right of those who make the laws to change them at their pleasure when circumstances may seem to require. With the wisdom of the proposed change, the courts are not concerned." 32

San Francisco, California.

Louis Bartlett.

28 Cal. Const., Art. IV, § 35.

28 County of Colusa v. Weich (1898) 122 Cal. 428, 431, 55 Pac. 243; Foltz v. Cogswell (1890) 86 Cal. 542, 550, 25 Pac. 60.

30 Marshall v. Baltinore, etc. R. R. Co. (1853) 57 U. S. (16 How.) 314, 334, 14 L. Ed. 953.

31 Collier v. Lindley, supra, n. 1.

32 Taylor v. Hoag (1922) 273 Pa. 194, 199; 116 Atl. 826. 